\title{
Impact of Education and Parent Learning Effect on Student Learning Achievement of School Students Country Je'netallasa District Gowa.
}

\author{
Yuddin Passiri
}

\begin{abstract}
Problems examined then this type of research using quantitative research. Quantitative data is data that is expressed in numerical terms. Quantitative data used in this study, among others, data obtained through questionnaires and student achievement data. By using three variables, namely the variables $X_{1}$ (level of education), $\mathrm{X}_{2}$ (income) and $Y$ (student achievement), this study sought to discover whether there is a significant influence between education and income levels of parents to the student achievement School Students basic Je'netallasa District of Gowa Regency. The population that the researchers specify is the whole elementary school students Je'netallasa District Gowa Year 2014/2015, with population research is not a sample study because the number is less than 120 people.From the above data can be seen that the distribution of questionnaires returned to the researchers as many as 82 respondents, while Others did not return or not filled or damaged, so the sample in this study was 82 parent pair of students consisting of father 82 respondents and father 82 respondents so that the total is 164 which made the respondent in this research. The result of this research is the positive and significant influence of parent education level to the learning achievement shown by the partial determination test obtained the contribution value of $7.5 \%$, the positive influence and the significant level of income on the learning achievement which is shown by the partial determination test obtained by the contribution value of $17.9 \%$ And the positive and significant influence of the level of education and the level of income on the learning achievement shown by the simultaneous determination test obtained by the contribution value of $3.47 \%$ and the remaining $96.53 \%$ influenced by other factors not included in the research variables.
\end{abstract}

\section{Background}

Education is one of the main factors for the development of human resources because education is believed to increase human resources so as to create productive human beings capable of advancing the nation, (Kunaryo, 2000). Education is an ongoing process for life and is carried out in the family, school and community environment, because education is the responsibility of family, community and government.

In Indonesia, education has become one of the most important factors in its development and progress. Evidenced by the reform in the field of education by the government, among others: improving the quality of education, curriculum updates in accordance with the development of science and technology, and the provision of adequate facilities and infrastructure. Learning achievement is a reflection of the learning effort. Learning achievement is also the result obtained by every child or student after learning activities. Optimal learning activities will affect the success rate of student achievement in learning. Student achievement will be obtained maximally through a structured learning process. Learning achievement is the result of the effort achieved by students during the learning activities in schools that produce a value. The success of students in learning will be shown from the value obtained has reached the minimum completeness criteria (KKM) that have been determined. Based on these requirements, students are expected to achieve optimal results. A person with high achievement can be said to have succeeded in learning. Learning achievement is the degree to which the child's knowledge of the material received (Slameto, 2010: 17).

Although for the criteria of KKM schools vary, for those who are in the city will be different from those in the village. In addition to where the school is located things that affect student achievement in school will be taken into account in the determination of minimal criteria mastery. A student must pass or excel with value calculation and compared with a minimum completeness criteria in all subjects. Students who are in the city can be said to be easy in reaching KKM from the point of view of meeting the needs of students in learning. This can be seen from the background of the student's own parents. Parents of students residing in the village will be different from those in the city, from the level of education and income levels. Rural communities can be said rat a -rata poorly educated because most of them are less concerned with education during their school age, while the income level can be seen on the types of jobs in the countryside that mostly work as farmers and traders. While the parents are the first and primary education center for a child so it can determine in the success of learning (Slameto, 2003: 61). Parents who have a high education level usually have high ideals also on the education of their children. They want their children's education to be higher or at least equal to their parents' education, these ideals and impulses will affect the attitudes and success of their children in school. One indicator of the success of learning can be seen from the achievement of learning. Self-achievement is a positive result that shows the image of a person's success in an activity or learning process in the form of 
changes in the aspects of cognitive, affective and psychomotor in an effort to optimize the ability it has through an activity that followed. Learning achievement is an educational assessment of student progress and progress regarding the mastery of the lesson material presented to them as well as the values contained in the curriculum after an evaluation activity.

In essence the learning achievement is a process of individual self-change with the possession of new experiences where the changes that occur manifest into patterns, behaviors that are in the affective, cognitive and psychomotor areas, deeds, skills and knowledge and can be seen from the learning itself. Thus the learning achievement reflects the success of teaching and learning activities. So it can be concluded that the essence of learning is a change but not every change is the result of learning.

The quality of education is closely related to the learning achievement. Learning achievement is the maximum result achieved by someone after going through the learning process. Furthermore, the process of learning depends on the quality of the learning process in the classroom, which involves the role of teachers, curriculum, funds, facilities, infrastructure and students themselves. In the learning process, the student's task is to learn and the role of the teacher is to encourage, assist, help students to learn. Student achievement will be achieved optimally if accompanied by hard work. Hard work is part of achievement motivation. In addition to the above issues that are not less important is the problem of economic circumstances. The state of the family economy or the income of parents is closely related to the child's learning. Children who are studying in addition must be fulfilled their basic needs (eg food, clothing, health protection) as well as the intensity of support facilities and learning infrastructure must be met (eg table, chair, lighting, stationery, books and others). The learning facilities can only be met if the family has enough money.

The economic condition of the family will have an effect on the development of the children, if it is noticed that with the existence of an adequate economy, the material environment faced by the child in his family is wider, he will get a wider opportunity to develop various skills that he can not develop if No prasarananya (Gerungan, 2004: 196). The reason researchers took the title "The Impact of Income Level Education Level Parents And Influential In Student Achievement Elementary School State Je'netallasa Gowa" ari d due to the observation of researchers that elementary school students of State Je'netallasa Gowa Derived from different socio-economic conditions of the family, such as: the level of education, income, property owned and residence so that researchers want to know whether there is influence of socio-economic conditions of parents on learning achievement.

\section{Education}

\section{Literature Review}

Understanding education is one of the processes in which a nation prepares its young generation to live life and meet the purpose of life effectively and efficiently. Education is more than teaching, because in reality education is a process in which a nation or country fosters and develops self-awareness among individuals. With that awareness, a nation or country can pass on cultural richness or thought to the next generation, so that it becomes an inspiration to them in every aspect of life (Azyumardi Azra: 1999).

Educational experts have interpreted the meaning of education. Understanding-understanding is very diverse, so there are differences depending on the figure looking at it. Although there are different views on the meaning of education, there are generally similarities in formulating the meaning of education. According to John Dewey (Ibid 2: 1999) education is "the process of intellectual and emotional fundamental skills formation towards the natural and the fellow human beings". According to KH Dewantara (Ibid 4: 1999) "education is the guidance in the life of the children, wherever it is meant, education is to guide all the natural forces that exist in the children, so that they as human beings and as members of society can achieve salvation and The highest happiness "

In the Dictionary of Contemporary Indonesian (Peter and Yenny 4: 1991) described the notion of education as follows: Education is the process of guiding people from darkness, ignorance and intelligence knowledge. In the sense that both formal and informal education covers everything that extends all the human knowledge of itself and about the world in which it lives. From the above information it can be concluded that education is the effort for humankind to consciously aim to develop the physical and spiritual of the students to the goals aspired by education, it implies that education is a continuous process. It is a continuous but steady repetition of repetition that comes to the desired shape. On the other hand education is very important for human life, it is an absolute necessity must be met to maintain the existence of mankind or it can also be said that education is the guidance or guidance must be able to realize the potential possessed by students who are growing and developing both physical And spiritual.

\section{Socio-Economic Condition}

Socioeconomic conditions of each person is different and multilevel, there are social conditions high, medium, and low economic. The social economy according to Abdulsyani (1994) is the position or position of a 
person in a group of people determined by the type of economic activity, income, education level, type of house, and occupation in the organization, whereas according to Soerjono Soekanto (2001) socioeconomic is one's position in society Relating to others in the sense of the environment of peraulan, achievement, and rights and obligations in relation to resources. Based on some opinions above, it can be concluded understanding of socioeconomic conditions in this study is the position or position of a person in the community related to the level of education, income level of property or facilities and type of residence. By virtue of the nature of human beings are born to have equal and equal status, but in accordance with the reality of every human being who becomes a citizen of a society, always have status or position and role. There are several factors that can determine the high level of socioeconomic conditions of parents in the community, including the level of education, type of work, income level, environmental conditions tingal, property ownership, and participation in group activities from the community. In this case the description is limited to only 4 factors that determine the level of education, income, and ownership of wealth, and type of residence.

\section{The Essence of Learning Achievement}

Achievement is basically the result of an activity. While learning is basically a process that results in individual self-change, ie behavior change. Thus the learning achievement is the result obtained in the form of impressions that result in changes in the individual as a result of activity in learning. In today's increasingly advanced and complicated society, one's achievements are seen as very important. Educational institutions emphasize the importance of good learning performance, competition and success both in tests, both knowledge and ability tests. To facilitate in understanding about the understanding of learning achievement, need to gain further understanding about the meaning of achievement. Achievement is the result of an activity that has been done, created, both group and self. In the popular dictionary it is stated that achievement is what has been created, the results of work, the results of which are pleasantly earned by the way of work perseverance.

From the above understanding can be observed the same meaning, which in essence is the result that has been achieved from an activity, therefore it can be understood that the achievement is the result of an activity that has been done, created, and pleasures obtained by way of work individually or Groups in a particular field. While the achievement word itself comes from the Dutch language is Indonesian prestatie later in the sense of accomplishment is "what has been produced and created" achievement is one of the goals of a learning and activity as well as a motivator to the students. While the word learning means a process of business undertaken by individuals to obtain a change in behavior as a whole as a result of individual experience to obtain a whole new behavior change as a result of individual experience itself in interacting with the environment.

\section{Effect of Parents Education Level on Learning Achievement Child Understanding Parents}

Based on the things mentioned above can be obtained the notion that parents are not only enough to feed, drink and clothing only to his children but must try to make his son be good, clever, happy and useful for his life and society. Parents are required to be able to develop all the potential of their children so that physically and spiritually can develop optimally and in balance.

\section{Level of Formal Parent Education}

The level of formal education of parents is the level of final education that is owned by parents, whether it is the level of primary school (SD), junior high school (SMP), Senior High School (SMA), and Academy Institute or University.

\section{Duties and Roles of Parents}

In addition, parents must also be able to develop the potential of children, modeling and able to develop the growth of personality with full responsibility and affection. The parents consciously assume the obligation to maintain and nurture their children until they are able to stand on their own (adult), physically, socially, economically, as well as morally and religiously. Mentally so that children grow smart and brilliant, then in addition to the completeness of nutrition should also be given the motivation to learn along with adequate facilities and learning infrastructure. Parents are part of the family, which is the primary primary educational place for adult children, it is also the place where the protege first receives education and guidance from parents or from family members.

\section{Influence of Socio-Economic Condition on Learning Achievement}

According to Hamalik (1983) good socioeconomic conditions can be inhibiting or encouraging in learning. The issue of tuition fees is also a source of strength in learning because of the lack of education costs will greatly disrupt the smooth learning. One of the facts that affect the level of children's education is family 
income. The socio-economic level of the family has a high influence on student achievement in school, because all the needs of children with regard to education will require the social economy of parents. While the indication of learning achievement is an indicator of the success of learning that leads to the success of education. As has been known that learning achievement is one of the results achieved after experiencing this process itself but requires external stimuli that can generate the process.

\section{Research design}

Problems examined then this type of research using quantitative research. According Sulistyo (2010: 12), quantitative data is data expressed in the form of numbers. Quantitative data used in this study, among others, data obtained through questionnaires and student achievement data. By using three variables, namely the variables $\mathrm{X}_{1}$ (level of education), $\mathrm{X}_{2}$ (income) and $\mathrm{Y}$ (student achievement), this study sought to discover whether there is a significant influence between education and income levels of parents to the student achievement School Students basic Je'netallasa District of Gowa Regency. Types and sources of data collected can be primary and secondary data, as follows: Primary data, data obtained directly through questionnaires filled by students about the level of parent education, motivation and economic level defined by the average income each month. Secondary data, data obtained directly from school about achievement (result) of student learning that is in the form of report card value semester 1 academic year 2015/2016. Data collection methods used in this study are as follows: In this study, a questionnaire method used to obtain information from respondents about the condition of the level of education, motivation and level of parental income elementary school students of State Je'netallasa Gowa 2015/2016 school year. Documentation is done by recording / citing existing data in elementary school students Je'netallasa State Gowa District taken by elementary school students Je'netallasa District Gowa Year 2015/2016. The data needed in this research is secondary data in the form of average value of report cards. The population that the researcher determines is the entire elementary school students of Je'netallasa State Gowa Regency 2015/2016 year, with non population research sample study because the number is less than 120 people. Distribution of the questionnaires returned to the researcher as much as 82 respondents, while others did not return or not filled or damaged, so the sample in this study was 82 parent pair consisting of father 82 respondents and father 82 respondents so the total is 164 respondents this research.

\section{Research result}

The elementary school students of Je'netallasa Regency of Gowa in 2015/2016 have several buildings that are still used, namely the headmaster room, vice principal room, teachers room, administrative room, classroom, BP and UKS room, employee room, , Computer lab, sewing room, canteen, mosque, cooperative, kitchen, bathroom / toilet, and hall.

\begin{tabular}{|l|r|r|r|r|r|}
\multicolumn{1}{|c|}{ ANOVA } \\
\multicolumn{1}{|c|}{ Model } & Sum of & Df & Mean Square & F & Sig. \\
\hline Squares & 256.129 & 2 & 128.065 & 17.165 & \\
Residual & 589392 & 79 & 7461 & & \\
Total & 845.521 & 81 & & & \\
\hline
\end{tabular}

a. Predictors: (Constant), Parent Revenue Level, Parent Education Level

b. Dependent Variable: Learning Achievement

Source: Result of Research Analysis, Year 2016

This test is conducted to determine whether there is influence of independent variables on the dependent variable simultaneously. Based on the F test, F calculate is 17,165 and the significance level 0.000 is much smaller than the level of significance used is 0,05 . Based on these results (Ho) rejected, meaning there is a significant influence between independent variables on the dependent variable together. Thus Hypothesis (H1) which states that there is a significant influence simultaneously between parent education and parent income on student achievement is accepted.

\begin{tabular}{|c|c|c|c|c|c|c|c|c|}
\hline \multirow[t]{2}{*}{ Model } & \multicolumn{2}{|c|}{$\begin{array}{c}\text { Understandized } \\
\text { Coeficients }\end{array}$} & $\begin{array}{l}\text { Standardized } \\
\text { Coefficients }\end{array}$ & \multirow[t]{2}{*}{$\mathrm{T}$} & \multirow[t]{2}{*}{ Sig } & Correlations & \multicolumn{2}{|c|}{ Collinearity Statistics } \\
\hline & B & Std. Error & Beta & & & Partial & Tolerance & VIF \\
\hline $\begin{array}{l}1 \text { (Constant) } \\
\text { Level of } \\
\text { education } \\
\text { Parents } \\
\text { Income Level } \\
\text { Parents }\end{array}$ & $\begin{array}{c}68.567 \\
.032\end{array}$ & $\begin{array}{l}.992 \\
.015\end{array}$ & .229 & $\begin{array}{l}69.122 \\
2.123\end{array}$ & $\begin{array}{l}.000 \\
.037\end{array}$ & .232 & .758 & 1.319 \\
\hline
\end{tabular}

a. Dependent Variable: Learning Achievement

Source: Result of Research Analysis, Year 2016 
The influence of parent education on student achievement. Based on the results of $t$ test calculation for parents education variables obtained t Count of 2.123 because $t$ is expressed with a positive sign, the higher the parent education the higher the student achievement. With a significant number of $0.037<0.05$ then $\mathrm{H}_{0}$ is rejected, $\mathrm{H}_{2}$ is received. This means that there is significant relationship between parents' education Effect $\left(\mathrm{X}_{1}\right)$ on student achievement (Y) partially. Effect of parent income on student achievement. Based on the results of $\mathrm{t}$ test calculation for parents education variables obtained t Counted 3.711 because $t$ is expressed with a positive sign, the higher the parent's education the higher the student achievement. With a significant figure of 0.000 $<0.05$ then H0 is rejected, H3 accepted. This means there is a significant influence between the influence of parent education (X2) on student learning achievement (Y) partially.

\section{Discussion}

\section{The Influence Of Education And The Influence Of Parents Income Against Student Achievement}

The results showed that the levels of education and parents pandapatan effect on student achievement simultaneously, so that $\mathrm{H}_{1}$ is accepted. This can be from the $\mathrm{F}$ test, which shows a level of significance of 0.000 is much smaller than the level of significance used is 0.05 . In this study student achievement classified in enough criteria that is equal to $97.56 \%$ enter in enough criteria and the rest of $2.44 \%$ is high. Parents education is mostly the level of junior high school education (father of $45.12 \%$ is junior high and mothers $41.46 \%$ are elementary school). While the income of parents is high, this is indicated by the income of the father belonging to very high criteria of $45.12 \%$ and income of mothers by $40.24 \%$ is the level of income that enter the criteria is high enough. According to Sumarto (2006) in a study entitled the influence of socio-economic conditions and education of parents on the motivation to continue education to college. Shows that the influence of socioeconomic condition of parents influences the motivation to continue education to university is $4.48 \%$, while the influence of parent education influence motivation to continue education to university is $3.61 \%$.

\section{Effect of Parents Education on Student Achievement}

In this study states that parental education partially influence on student achievement. This can be seen based on the results of $t$ test calculation for parents education variables obtained t Calculate for 2.123 because $t$ is expressed with a positive sign, the higher the parent education the higher the student achievement. According to Ahmadi (1997: 289) educated parents will give more attention to children especially in the field of education with the hope that in the future the quality of life is better than ever. So a highly educated parent will educate his or her child at least equal to that parent's education then, even if it can exceed the education of the parents.

Parental education in this study shows that the average of education is less. This can be seen in table 4.6 and 4.7 which is the education of father and mother who mostly are junior and elementary school. However, when viewed from the presence or absence of donations on student achievement and student achievement can be said parents studied successfully. The results above are in line with the results of research conducted by Rohidin (2006) entitled the influence of education level and encouragement of parents to the achievement of second grade students of SMK Triguna Utama Ciputat Tangerang Banten. In the research there is a positive influence between the level of education and encouragement of parents to the achievement of second grade students of SMK Triguna Utama Ciputat Tangerang Banten.

\section{Effect of Parent's Income on Student's Achievement}

In this research states that parent income level partially influence to student's learning achievement, it is based on the calculation of $t$ test for parents education variables obtained t Count of 3.711 because $t$ is expressed with a positive sign. In addition, in general, children from middle to upper class families get more direction and good guidance from their parents. Children with low economic backgrounds, lacking adequate guidance and direction from their parents, as parents focus more on how to meet their daily needs. Most of the parents 'income is already high, and generally the students' achievement is good and complete. This can prove that with good parent student income hence achievement of student also good. One of the facts that affect the level of children's education is family income. The socio-economic level of the family has a high influence on student achievement in school, because all the needs of children with regard to education will cost from parents. According to research conducted by Maftukhah (2006) the effect of the resulting socio-economic conditions of parents on student achievement. Influence in the study was quite large that is equal to 55, 06\% of student achievement. The same result is shown in research of Syriac (2006) entitled influence of social condition and economics of parent to motivation to continue education to college, and result show significant result equal to $35,6 \%$

\section{Conclusions And Recommendations}

This study aimed to determine the effect of educational level and income level of parents of elementary school students learning achievement of State Je'netallasa Gowa. Based on the results of research and discussion can be concluded as follows: There is a positive and significant influence of parental education level on the learning achievement shown by the partial determination test obtained by the contribution value of $7.5 \%$. 
There is a positive influence and significant level of income on learning achievement which is shown by partial determination test obtained by contribution value of $17.9 \%$. There is a positive and significant influence of education level and income level on learning achievement which is indicated by simultaneous determination test obtained by contribution value of $3.47 \%$ and the rest $96.53 \%$ influenced by other factors not included in research variable.

\section{Suggestion}

Looking at the results of research that has been done, suggestions that researchers can provide in this study as follows: Because of the relationship between the level of education and the level of income parents with learning achievement of children, parents are expected to always supervise the direction and guide the child in learning, and can meet the learning needs of children. For students is expected to grow the learning achievement to reach high ideals with the role of parents who will always guide and try to meet the needs of learning. For the school to always create and realize the school environment that is familiar and peaceful and comfortable to carry out the process of teaching and learning, so it is expected that student learning achievement be good and optimal, because the school environment and family environment is one of the factors of student learning success / student achievement.

Great, Revelation. 2010. Free SPSS 17.0. Jogjakarta: Garailmu

[2]. Ahmadi, Abu. 1997. Basic Social Sciences. Jakarta: Rineka Cipta

[3]. Algifari. 2000. Regression Analysis. Yogyakarta: BPFE UGM.

[4]. Anni, Chatarina Tri, et al. 2006. Psychology of Learning. Semarang: UPT MKK UNNES.

[5]. Arikunto, Suharsimi. 1998. Research Procedure A Practice Approach. Jakarta: Rineka Copy.

[6]. 2002. Research Procedure A Practice Approach, Jakarta: Rineka Copyright,

[7]. Ministry of education and culture, 1998. Dictionary of Indonesian, Jakarta: Balai Pustaka.

[8]. Darmaningtyas. 1999. Education in and After the Crisis (Evaluation of Education in Times of Crisis), Yogyakarta: Student Library.

[9]. Gerungan. 2004. Social Psychology. Bandung: PT Refika Aditama.

[10]. Ghozali, Imam. 2005. Applications Multivariate Analysis With SPSS Program. Semarang: Diponegoro University Publishing Agency.

[11]. Ny Gunarsah Singgih D. 1976. Psychology for Families, Jakarta: Mountain Majesty.

[12]. Habeyb, SF 1983. Popular Dictionary. Jakarta: Centra.

[13]. Hadikusumo, Kunaryo. 2000. Introduction to Education. Semarang: Semarang Teachers' Training College press.

[14]. Heini, Rita. 1999. Influence of Parents' Socioeconomic Condition on the achievement of students of grade 3 high school N 1 Pekalongan. Economic Education UNNES Semarang.

[15]. Leksono-Supelli, Karlina. 2000. Parents in Children's Education. Http: //arusbawah20.wordpress.com/2010/07/24/revolutionpersonal thinking-parents-in-education-children /. (October 7, 2010).

[16]. Maftukhah. 2007. Effect of Socio-Economic Conditions of Parents Against Student Achievement Geography Student Class VIII SMP N 1 Randudongkal District Pemalang Year 2006/2007. Economic Education UNNES Semarang.

[17]. Neuenschwander. Mark P. 2007. International Journal of Behavioral Development. Http: // jbd. Sagepub. Com / content / $31 / 6 / 594$. Full. Pdf + html. (October 7, 2010).

[18]. RI Government Regulation no. 27-28-29 30 of 1990 on the Implementation of the National Education System. 1990 . Jakarta: Kloang Klede Jaya

[19]. Poerwodarminto, WJ S. 2002. General Indonesian Dictionary . Jakarta: Balai Pustaka.

[20]. Rohidin. 2006. Effect of Education and Encouragement of Parents Against Child Learning Achievement Vocational Class II Main Triguna Ciputat Tangerang. Department of Economics, Faculty of Social Sciences, State University of Semarang.

[21]. Sadirman MA 1994. Interaction of Teaching and Learning and Motivation , Jakarta: PT. King Grafindo Persada.

[22]. Slameto. 1987. Learning and Factors Affecting . Jakarta: Bina Script.

[23]. 1995. Learning and Factors Affecting . Jakarta: Bina Script.

[24]. 2000. Learning and Factors Affecting . Jakarta: Bina Script.

[25]. 2003. Learning and Factors Affecting . Jakarta: Bina Script.

[26]. 2010. Learning and Factors - Factors Affecting . Jakarta: Rineka Reserved.

[27]. Sumardi, Mulyanto and Dieter-Evers, Hans. 1982. Poverty and Supplies Principal. Jakarta: Eagles.

[28]. Sumarto. 2006. Effect of Socio-Economic Conditions and Parent Education Motivation for College Continuing Education in High School Students NU Wahid Hasyim 01 Gutter Academic Year 2005/2006. Department of Economics, Faculty of Social Sciences, State University of Semarang.

[29]. Suryani, Nanik. 2006. Influence of Social Condition and Economic K0ndisi Parent Motivation to College of Continuing Education . http: // journal. UNNES. air conditioning. en / index. php / DP / article / view / 476.

[30]. Lecturer team FIP, Malang Teachers' Training College. 1978. Introduction to the Basics of Education. Surabaya: National Business.

[31]. Teachers' Training Development Team MKDK Semarang. 1989. Fundamentals of Education. Semarang: Semarang Teachers' Training College Press.

[32]. Dictionary Indonesian Banking Development Team. Indonesian Banking Dictionary. 1980, Jakarta: Institut. Bankers Indonesia.

[33]. Act No. 20 Year 2003 on National Education System . 2003. Jakarta: Sinar Grafika

[34]. RI Law \# 2 of 1989 On the National Education System. 1992. Jakarta: Balai Pustaka.

[35]. Watkin, Thomas. 1997. Parenting - Influence Of Parents' Level Of Education Children, Parental, School, Educational, Child, and Achievement http: // education. stateuniversity. com / pages / 2311 / Parenting-INFLUENC -PARENTS-LEVEL EDUCATION. html \# ixzz1RsLj1QOQ (7 October 2010) 